\title{
地下水中への長期間の空気注入による 污染物質濃度変化について CHANGE OF CONTAMINANT CONCENTRATION BY LONG TERM AIR INJECTION IN GROUNDWATER
}

\author{
江種伸之 ${ }^{1} \cdot$ 平田健正 $^{2} \cdot$ 福浦清 $^{3} \cdot$ 松下孝 $^{3}$ \\ Nobuyuki EGUSA, Tatemasa HIRATA, Kiyoshi FUKUURA and Takashi MATSUSHITA \\ 1正会員 博 (工) 和歌山大学助手 システム工学部（テ640-8510 和歌山県和歌山市栄谷930） \\ ${ }^{2}$ 正会員 工博和歌山大学教授 システム工学部（同上） \\ 3 前澤工業株式会社 土袞環境部（テ332-8556 埼玉県川口市仲町5-11）
}

\begin{abstract}
The air sparging coupled with the soil vapor extraction as the physical remediation technologies has been applied to a site contaminated with volatile substances like tetrachloroethylene. In order to implement these technologies, it is indispensable to understand the mechanism of air migration injected in groundwater and the change of groundwater concentration. In this paper, we presented the results of full scale field experiment implemented to estimate the change of groundwater concentration caused by long term air injection in groundwater. As a result, it was clarified that the change of groundwater concentration within the radius-ofinfluence was caused by volatilization into injected air and stirring of groundwater by air injection.
\end{abstract}

Key Words : groundwater contamination, volatile substances, remediation technology, air sparging, full-scale field experiment

\section{1.はじめに}

揮発性のトルエンやテトラクロロエチレンなど によって污染された地下水・土壌環境から污染物 質を除去する技術として，最近ではその揮発性を 利用したエアースパージング技術が注目されてい る1). エアースパジング技術とは, 地下水中に空気 を吹き込み，地下水を膡汼することで溶解してい る物質を注入空気に揮発させ，不飽和帯からガス として除去するものである. さらに, 地下水中に 酸素を供給することになるので, 微生物分解を促 進させる効果も期待されている2)。こり技術は揮発 性物質に対して行う地下水揚水処理と比べると, (1)污染された地下水の処理が不要になる, (2)地上 設備の設置が簡単, (3)費用が安くなる, (4)実施期 間が短くなるなどの利点がある. しかし，空気を 吹き込むことで地下水が乱されるため, 地下水や
土壤ガス中の物質回収量に影響が生じる。また, 污染物質を周辺へ拡散させる危険性もある.

すなわち，エアースパージング技術を本格的対 策として現場で実施していくためには，注入され た空気の影響範囲や移動特性, 空気通過による物 質濃度変化の様子を明らかにしておかねばならな い.これまでには, Ji et al.の室内実験 ${ }^{3)}$, Unger et al. の数值シミュレーション4)などの研究例が報告され ている. また, 著者らも揮発性物質によって地下 水が污染された現場でエアースパジング技術に関 する実証実験を行い, 地下水中に注入した空気の 影響範囲や注入空気中に揮発した物質濃度の算定 を行ってきた5),6).

本稿では, 長期間に渡って実施した実スケール 野外実験の結果をもとに, 地下水中に注入された 空気が地下水中の物質濃度変化に及ぼす要因につ いて検討した. 


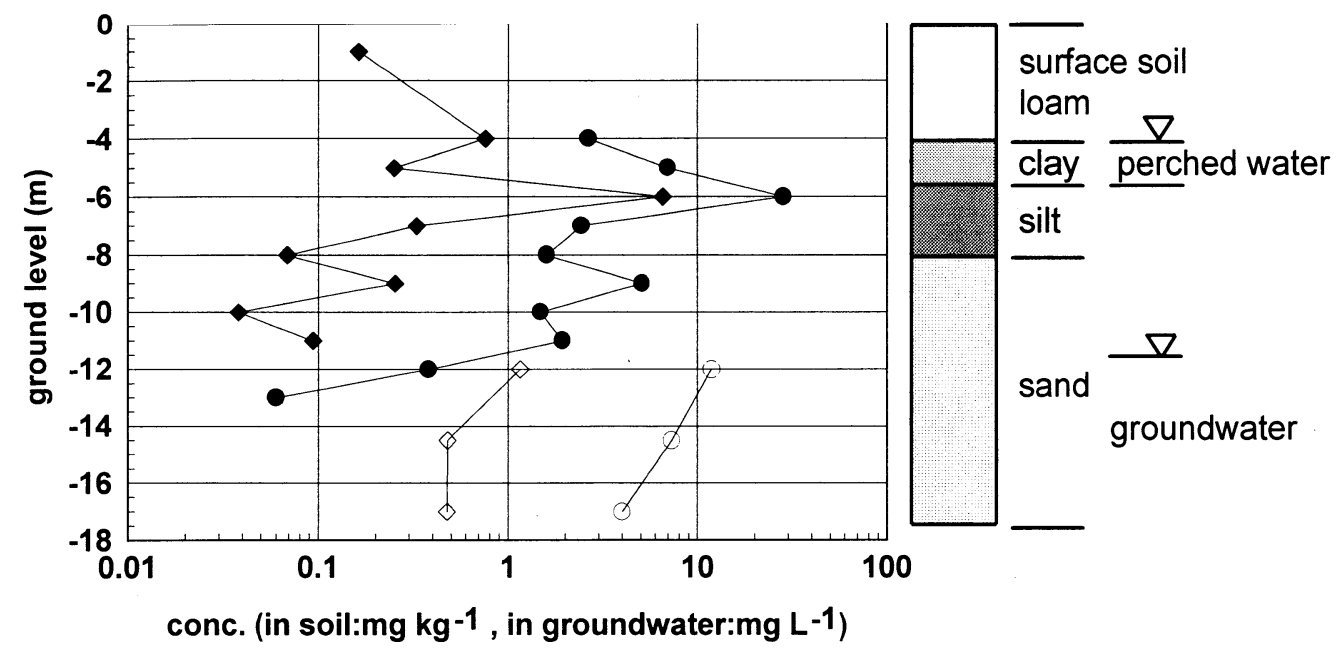

:toluene in soil, $\bullet$ tetrachloroethylene in soil

$\bigcirc:$ toluene in groundwater, $\diamond:$ tetrachloroethylene in groundwater

図 1 現地地質状況および污染物質存在量

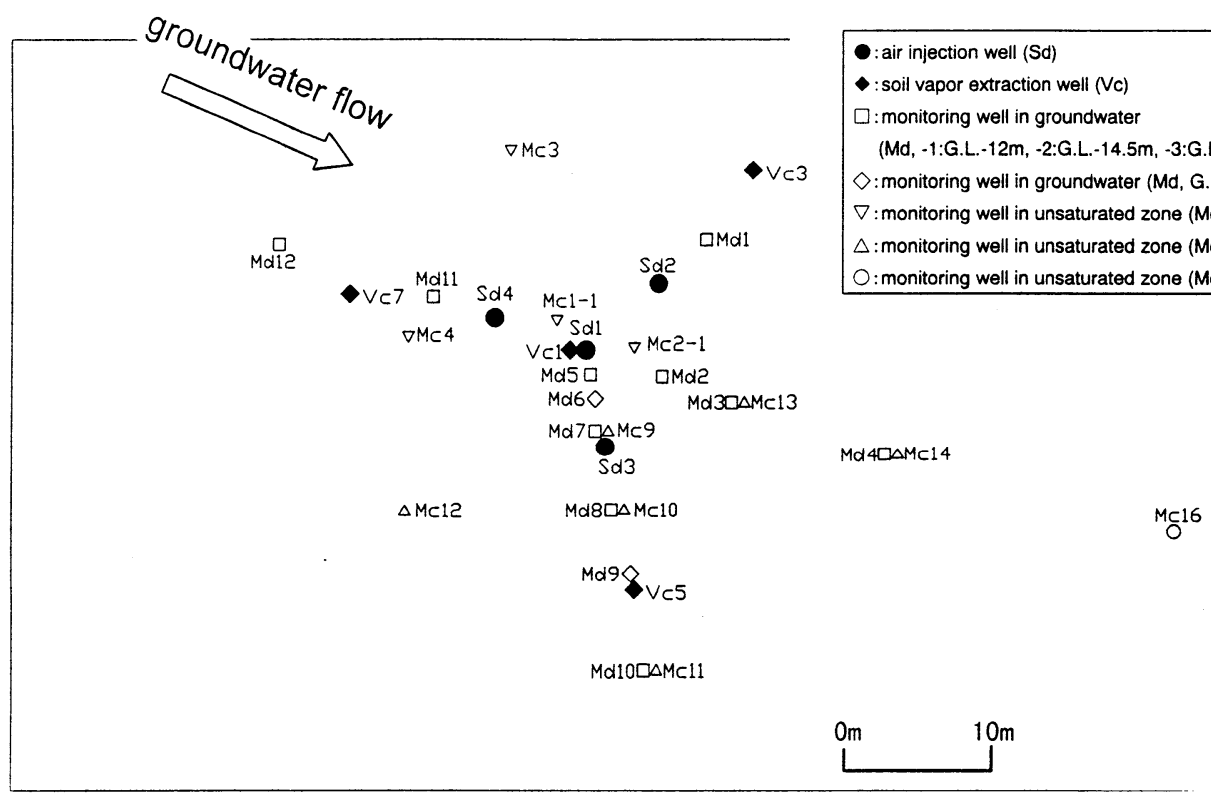

図 2 現地井戸配置図

\section{2. 現地概要}

実験場所は化学工場で, 現在は跡地になってい る. 現地の地質状況(図 1 )は，地表面からG.L.-4m までが表土とローム層, G.L.-5m過ぎまでが凝灰質 粘土層で, その下は砂質粘土, 砂質シルト, シル 卜質細砂と移行し, G.L.-8m過ぎから砂層となって いる．凝灰質粘土層の上には宙水帯が厚さ $1.75 \mathrm{~m}$ 程 度で存在しており，その下は不飽和帯を挟んで G.L.-11.5m付近から地下水帯を形成している(実験 中に季節変化でG.L.-12mまで低下).この地下水帯 はG.L.-30m以下まで続いているが, G.L.-17.5m付近 に固結した砂層があるため,ここを境として地下 水帯上部と下部に分かれる. 現地の地下水は北東
から南西方向に流れており, 流速は30m year-1程度で ある.

土壌中含有量の分析結果から, 地下環境中にはト ルエン, テトラクロロエチレンの2物質が多く存在 していることが判明した．また，地下水中濃度を測 定すると, 地下水面直下のG.L.-12m付近で高く, 深 度とともに低下する傾向を示した(図 1 ).

\section{3. 野外実験の概要}

\section{（1）井戸配置および構造}

現地での抽出井, 注入井, および観測井の平面配 置を図 2 に示している. 実験対象領域のほぼ中心部 

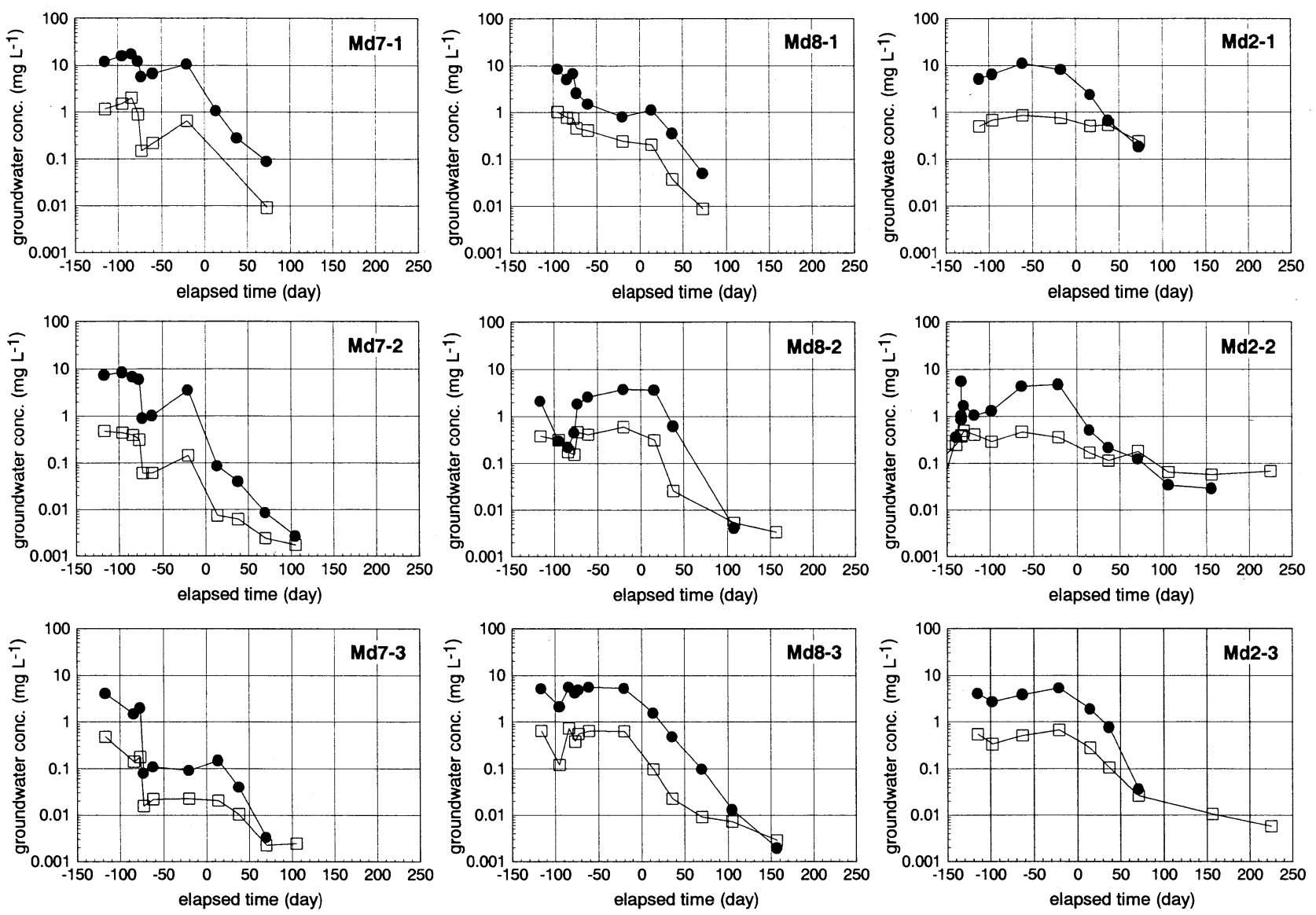

図 3 地下水中濃度の時間変化

トルエン, $\square:$ テラクロロエチレン)

(Sd1,Vc1)から注入井(Sd2,Sd3,Sd4)までの距離は6m, 抽出井(Vc3,Vc5,Vc7)までの距離は15mであり, 領域 外にガス態の物質が拡散しないように注入井の外 側を抽出井が囲む配置にした. なお, 注入井Sd1は 事前に行った短期運転のみで使用し5), 今回の実験 では注入井として Sd2,Sd3, Sd4の3本を使用した．抽 出井は上記の4本すべてを使用した.

注入井は深度G.L.-17.2mで, G.L.-16.7m〜17.2m地 点にスクリーンを設置した. 抽出井は深度G.L.-11m で, スクリーンをG.L.-7m〜11m地点の不飽和帯に 設置した. 地下水観測井はG.L.-12m(Md*-1), -14.5m (Md*-2),-17m(Md*-3)の3種類の深さで(Md6,Md9の 2本はG.L.14.5mのみ. 図 2参照), スクリーンを0.5m の厚さで各井戸底に設置した。不飽和帯観測井は 深度G.L.-9mを基本としたが，一部- $8 \mathrm{~m} や-10 \mathrm{~m}$ の のもある(図 2 参照). スクリーンは厚さ $0.2 \mathrm{~m}$ のの を各井戸底に設置した。

\section{（2）運転方法}

今回の実験では, 不飽和帯でガス抽出を行いな がら地下水中に空気を注入し, 運転の経過に伴う
地下水および土壤ガス中の物質濃度変化を観測した. 運転はまず土壌ガス抽出のみ開始した。空気注入は 予備実験等のために短時間行っていたが，本格的な 運転は土壌ガス抽出を始めてから約120日後に開始 し, 本稿ではこの時を起点とした経過日数を使って 時間を表す. 空気注入は3本の注入井 $(\mathrm{Sd} 2, \mathrm{Sd} 3, \mathrm{Sd} 4)$ を1本ずつ順番に120L min ${ }^{-1}$ の流量で1時間動かし, そ の間他の2本は休止させる間欠運転で行った。一方, 土壤ガス抽出は井戸1本当たり $120 \mathrm{~L} \mathrm{~min}^{-1}$ の流量で4本 同時(Vc1,Vc3,Vc5,Vc7)に連続運転を行った．注入 運転に関しては, 間欠運転を $4 \sim 6$ 週間続けた後に 1 週間の停止期間を設けた。これは注入運転停止中 に土壤ガスおよび地下水のサンプリングを行うため である．ただし，サンプリング中も抽出運転は継続 した.

\section{4. 結果と考察}

\section{（1）長期間の空気注入による物質濃度変化}

図 3 に注入空気の影響範囲内で5),6)地下水中濃度 の低下が顕著な観測井Md7,Md8およびMd2における 


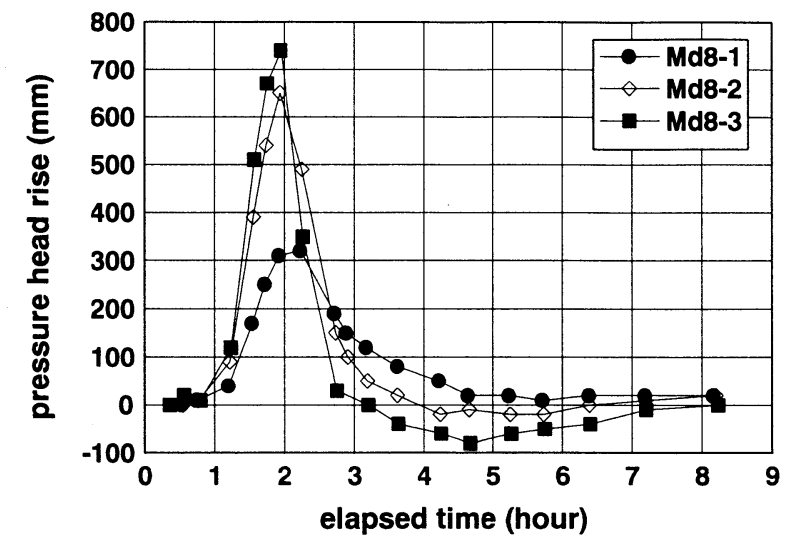

図 4 空気注入による地下水頭の上昇 (マウシディシグ試験結果)

地下水中濃度の時間変化を示している. 図中の -83日目から-74日目に濃度が低下しているのは, 短 期運転によるものである5). 長期運転を開始すると, Md7 とMd8では両物質とも濃度が大きく低下し始め, 100日目から150日目には検出限界以下(トルエン: $0.002 \mathrm{mg} \mathrm{L}^{-1}$,テトラクロロエチレン:0.003 $\left.\mathrm{m} \mathrm{L}^{-1}\right)$ にな る.ただし, G.L.-12mの70日目以降の值がないのは, 周辺地下水位の低下により採水ができなくなった ためである. また，Md2においても，Md7やMd8ほ どではないが, 空気注入を開始すると地下水中濃 度の低下が見られる.すなわち，長期運転では， 短期運転で影響の見られなかったMd8-2,-3，および 短期運転では観測井がなく空気注入の影響が確認 できなかった距離に位置するMd2でも濃度が低下し ていおり, 注入空気の影響が地下水面からの深さ に関係なく, 水平距離で $5.5 \mathrm{~m}$ 地点まで及ぶことに なる.

図 4 にマウンディング試験中のMd8における地下 水頭上昇高さの時間変化を示している. マウン ディング試験とは, 空気注入によって変化する地 下水頭を観測し, 水頭上昇の程度から注入空気の 影響範囲を調べる予備試験である。ここで, 空気 は1時から 2 時の間に注入されているが，注入運転 中は下部の観測井ほど地下水頭の上昇が大きく,

下から上に向かった動水勾配が発生している。一 方, 空気注入を停止すると下部の観測井で地下水 頭の回復が速く, 上部ほど地下水頭が高い状態に なる.すなわち, 上から下に向かった動水勾配が 発生している. 以上から, Md8地点では空気注入期 間中は地下水が上向きに流れ, 注入停止後は下向 きに流れている.この地下水の動きは, 空気の注

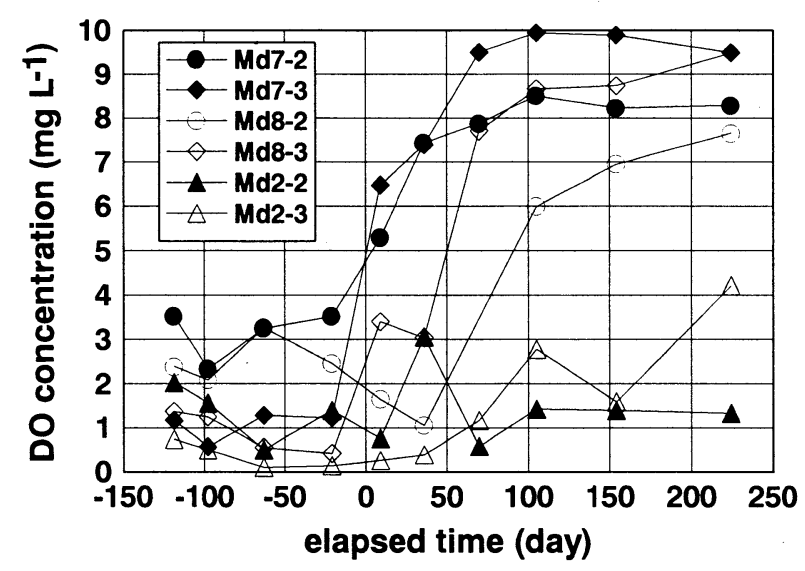

図 5 溶存酸素濃度の時間変化

入によって地下水が擋汼されている状態を示してい る. 今回の空気注入方法は, 3本の注入井のうちの 1本を1時間ずつ動かす間欠運転であることから, 長 期運転でもマウンディング試験中と同様な地下水の 動き(摚汼)が生じる.したがって, 注入空気への揮 発だけではなく, 地下水の擋挥による低濃度地下水 との混合も地下水中濃度の低下に影響を与えている と思われる. 観測井Md7およびMd8において, 注入 開始前に存在する観測井間の濃度差が, 注入運転を 開始すると次第になくなり(平均化され), 同じよう な低下傾向を示しているのが，擋汼による地下水の 混合の効果と見ることができる.

図 5 には，観測井Md7,Md8およびMd2における溶 存酸素濃度の時間変化を示している。ただし， G.L.-12m地点の值はべーラーで採水している影響な のか, 溶存酸素濃度に変化が生じていないため, 図 中には載せていない. しかし, 事前に両者の分析值 を比較したところ, 污染物質の濃度には有意な差は 見られなかった. Md7とMd8-3では, 空気注入開始 とともに溶存酸素濃度が大きく上昇する. Md8-2で は, 運転初期には溶存酸素濃度が低いが, その後は 直ちにMd7やMd8-3と同じ程度にまで上昇している. 短期運転では, Md8-2および-3付近にも量は少ない ものの注入空気の流れが確認されており5), 長期運 転中も空気通過の影響で溶存酸素濃度が上昇してい ると思われる.ただし, 前述したように, 注入空気 の影響範囲内では空気注入により地下水が擋拌され るため, 溶存酸素濃度の上昇には擋汼の影響も含ま れている. 一方, Md2-2では30日目に溶存酸素濃度 が上昇するが, 再び低下して 50 日目以降は $1.5 \mathrm{mg} \mathrm{L}^{-1}$ 程度で推移する. Jiほかの実験によると, 均一粒径 

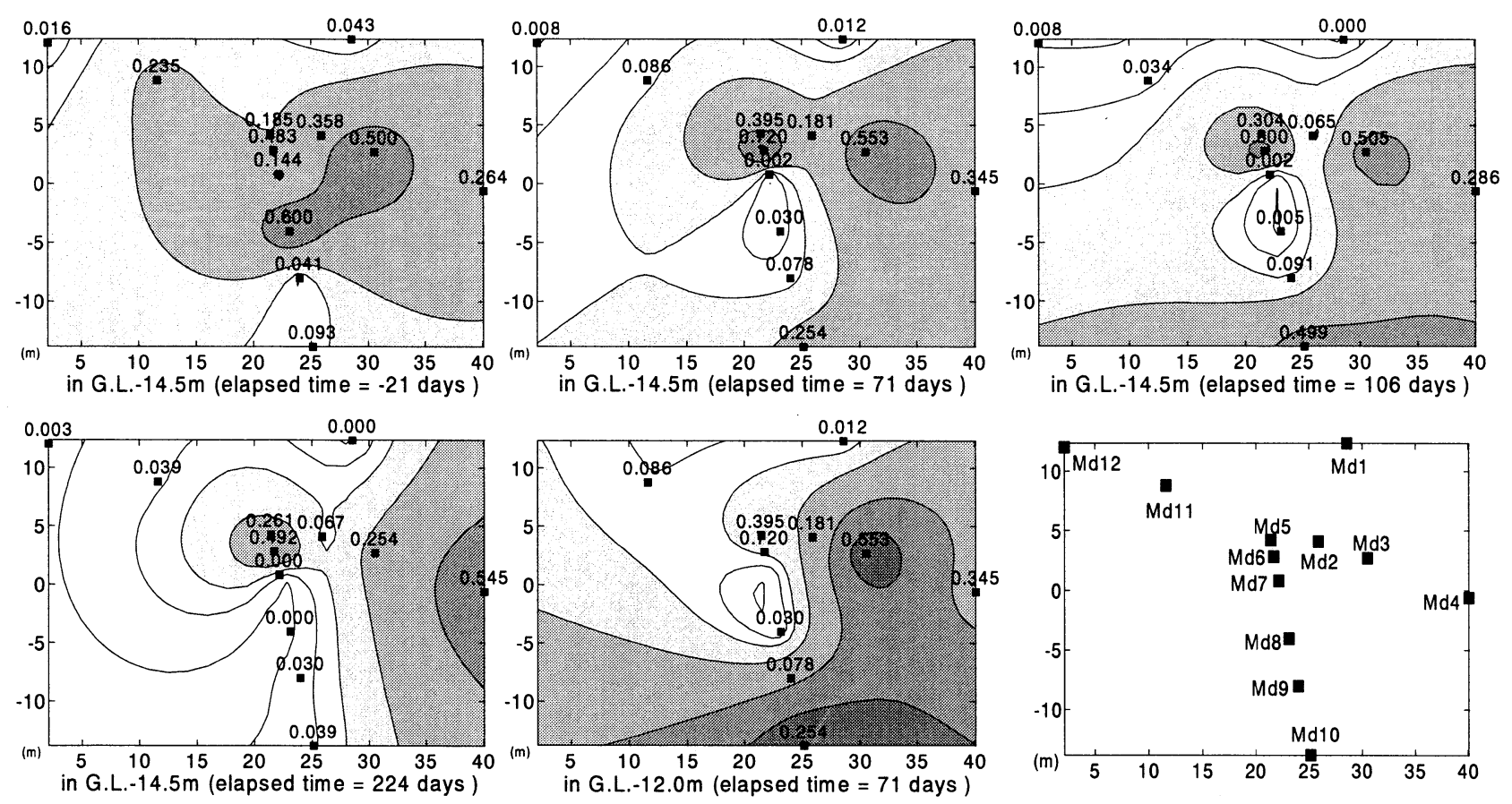

図 6 地下水中テトラクロロエチレン濃度の平面分布

の飽和多孔体中では注入された空気の流路形成に 異方性は生じないが, 複数の粒径の粒子が混在し ている多孔体では粒径の違いによる透過性の変化 によって局所的な異方性が生じることが確認され ている3). 自然土壤は通常粒径の異なる土粒子が混 在しているので, そこに注入された空気の流れに は局所的な異方性が生じていると考えられる。す なわち, 注入空気の影響範囲内でも空気が流れて いない場所が存在する. Md2-2では溶存酸素濃度が 運転中ほとんど上昇しないので, 注入空気の主な 流路になっていない可能性が強い。一方, Md2-3で は30日目までは溶存酸素濃度が低い状態にあるが, 50日目を過ぎたあたりから徐々に上昇しているこ とから, 小さいながらも注入空気の影響を受けて いる. 仮にMd2で地下水の摚汼が十分行われている ならば, Md2-2と-3の溶存酸素濃度は同程度になり， 観測井間では污染物質や溶存酸素濃度がMd7や Md8のように平均化されているはずである. すなわ ち, $\mathrm{Md} 8$ よりも注入井から水平距離でさらに $1.5 \mathrm{~m}$ 注 入井から離れているMd2では, 注入空気の流量が $\mathrm{Md} 7$ や $\mathrm{d} 8$ よりも少なく, また地下水の摚汼も小さ くなる. その結果, 観測井毎の地下水中濃度およ びその低下傾向に差が生じていると思われる.土 壌の局所的な異方性のため注入空気の影響が小さ いと考えられるMd2-2では, 特に地下水中濃度の低
下が小さい.

注入空気の影響範囲内(注入井から $5.5 \mathrm{~m}$ 以内)の観 測井では, 注入空気への揮発や地下水の摚汼による 低濃度地下水との混合によってトルエン, テトラク ロロエチレンとも注入運転中に濃度が低下していた. 特に, 空気通過量が多い場所では, 運転開始100日 か150日程度で検出限界以下になった。 ただし, 注 入空気の影響範囲内であっても, 土㙵中に空気が流 れにくい場所が発生し, その近辺では濃度の低下が 小さくなる. 注入空気の通過や地下水の擋汼の影響 は, 溶存酸素濃度や污染物質濃度の変化の傾向およ び観測井間で平均化されているかどうかである程度 判断することができる. ただし, 今後の課題として, 地下水の擋汼による污染の拡散を評価するために, 地下水中濃度の低下に及ぼす揮発や擋汼の効果を正 確に算定する必要がある.

\section{（2）注入空気の影響範囲外での物質濃度変化}

G.L.-14.5m地点および空気注入運転開始から71日 目のG.L.-12m地点における地下水中テトラクロロエ チレン濃度の平面分布を図 6 に示している. 実験対 象領域の大部分では, 空気注入運転の進渉とともに 濃度が低下している: 特に空気注入井から $5.5 \mathrm{~m}$ 以内 の観測井(Md1,Md2,Md7,Md8,Md11)で顕著に表れて いる.これらは注入空気の影響範囲内に位置してお 
り，注入空気への揮発や地下水の擋汼の影響と考 えられる.ただし，同じ影響範囲内の Md5,Md6で は濃度の低下が小さい。これは，前節で述べた Md2-2と同様，土壌を構成している土粒子の局所的 な粒径の違い(透過性の違い)によって空気流路の形 成に異方性が生じ，観測井周辺で空気の通過量が 少なくなっているためと思われる，一方，最寄り の注入井から水平距離で $10 \mathrm{~m}$ 以上離れている観測井 $(\mathrm{Md} 3, \mathrm{Md} 4, \mathrm{Md} 10)$ は，注入空気の影響範囲外と考え られ，濃度低下の様子が表れていない.

現地における地下水の流向から, Md3 と Md4は実 験対象領域の下流部に位置している. すなわち， ここには空気注入によって地下水中濃度が低下し た上流の影響が次第に及ぶと考えられる．地下水 の流速はおおよそ30m year-1なので，Md3には $5 \mathrm{~m}$ 上流 に位置するMu2の影響が約60口で及ぶ．Mu2-2では 濃度が $0.36 \mathrm{mg} \mathrm{L}^{-1}$ から， $0.18 \mathrm{mg} \mathrm{L}^{-1}$ (71日目), $0.06 \mathrm{mg} \mathrm{L}^{-1}$ (106日目)と実験期間中徐々に低下しているので, Md2-2の濃度低下の影響がMd3-2に及んでいるはず である。しかし，実際には106日目まで0.5 $\mathrm{mg} \mathrm{L}^{-1}$ 付近 で推移しており，Md2-2の影響が見られない。した がって, Md3-2で濃度が低下しない原因が他に存在 する. 周辺地下水位は, 季節変動によって注入開 始から100日で約 $35 \mathrm{~cm}$ 低下している. 江種ほかは, 地下水位が低下すると地下水面近傍の溶存態物質 が地下水中深くに浸入していく現象を数值シミュ レーションによって明らかにしている7)。このこと から，Md3-2で濃度が低下しない原因の一つに， Md3-1における高濃度地下水 $\left(0.76 \mathrm{mg} \mathrm{L}^{-1}\right)$ の下部への 浸入が考えられる. それ以降の地下水位が安定し ている2,3力月の間は，上部からよりも低濃度の上 流の影響が支配的になるため，224日目には濃度が 低下している．同様な傾向が最下流部のMd4や紙面 の都合で載せていないがMd3-3およびトルエンでも 見ることができる．詳細は省くが，Md4-2の224日 目の濃度(約 $\left.0.5 \mathrm{mgL}^{-1}\right)$ には, 地下水の流れによって上 流部(Md3方向)の影響が及んでいるものと考えられ る. Md10に関しても, 地下水位の低下によって上 部の影響を受け，Md10-2とも71日目，106日目には 濃度が上昇している。

今回の野外実験で, 注入空気の影響範囲外の一 部で実験中に濃度の上昇が見られた。しかし，こ れは空気注入による污染の拡散ではなく, 地下水
の流れや地下水位の季節変動による影響が大きいと 思われる．ただし，注入空気の影響範囲外にも直接 ではないが空気注入の影響が及ぶことが確認された ので,これまでにも指摘されているように，エアー スパージング技術の効果次第では污染の拡散の可能 性があり, 十分注意する必要がある.

\section{5. おわりに}

本稿では，エアースパージング技術に関する長期 間の実スケール野外実験を行い，地下水中に注入さ れた空気が物質濃度変化に及ぼす要因を検討した。 その結果, 注入空気の影響範囲内では, 空気への揮 発だけでなく, 空気注入による地下水の擋汼も物質 濃度変化に影響を及ぼしている. 土㙵中では注入空 気の流机に局所的な異方性が生じ，空気の流れにく い場所が存在するため, 地下水中濃度の低下に差が 出ていることが推察できた. また, 注入空気の影響 範囲外の濃度変化には, 空気注入による污染物質の 拡散は見られなかった。

今後の課題としては, 注入空気の影響範囲を定量 的に評価すること, 濃度低下に対する揮発と摚汼の 効果を判別すること, および物質毎の濃度低下の違 いを明らかにすることであり, 野外実験以外にも, 室内実験や数值シミュレーションを実施して解明し ていく予定である.

\section{参考文献}

1)例えばLundegard, P.D. and D. LaBrecue : Air sparging in a sandy aquifer (Florence, Oregon, U.S.A.): Actual and apparent radius of influence, Journal of Contaminant Hydrology, Vol.19,pp.1-27,1995.

2)ウィリアムC.アンダーソン編(軽部征夫監修) : バイオ レメディエーション, Springer,Tokyo,263p.,1997.

3)Ji, W. et al. : Laboratory study of air sparging: air flow visualization, Groundwater Monitoring and Remediation, Fall 1993,pp.115-126,1993.

4)Unger, A.J.A, E.A. Sudicky and P.A. Forsyth : Mechanisms controlling vacuum extraction coupled with air sparging for remediation of heterogeneous formations contaminated by dense nonaqueous phase liquids, Water Resources Research, Vo.31,No.8,pp.1913-1925,1995.

5)江種伸之ほか：地下水中に注入された空気の移動特性 および污染物質の濃度変化について, 水工学論文集, Vol.42,pp.349-354,1998.

6)江種伸之ほか：地下水中に注入された空気による水質 回復の効果について, 地下水学会誌, Vol.40,No.40, 印刷中, 1998 .

7)江種伸之ほか：トリクロロエチレンの自然河床区間か ら地下水系への浸透特性について，水工学論文集， Vol.36,pp.391-386,1992.

（1998. 9. 30 受付） 